\title{
理研ビームライン（BL45XU）における X線溶液散乱を用いた構造研究
}

\author{
理化学研究所 播磨研究所 藤澤哲郎
}

\begin{abstract}
Tetsuro FUJISAWA: Structural Studies on Protein Solutions by using Solution Xray Scattering Technique at RIKEN Structural Biology Beamline I (BL45XU)
\end{abstract}

RIKEN structural biology beamline I (BL45XU) is an undulator beamline with two branches. One is for protein crystallography (PX) and the other is for small-angle $\mathrm{x}$-ray scattering (SAXS). PX and SAXS experiments can be done simultaneously [Yamamoto et al. (1995) Rev. Sci. Instrum. 66, 1833-1835]. For SAXS branch the clean and stable optics were realized. The use of this beamline extends the various limits of small-angle scattering technique: measurements of dilute protein solutions, large protein complex and fast time-resolved experiments. These advantages will be fully utilized for high-pressure SAXS measurements.

\section{1.はじめに}

理研ビームライン I (BL45XU) は, SPring-8に設置さ れた構造生物学研究を目的としたビームラインで, 日本 で最初の結晶構造解析と小角散乱実験が同時に使用でき る分岐型挿入光源ビームラインである.1) 小角散乱とは, 散乱角が 10 度以下の回折・散乱を総称しており，その 内訳は大きく分けて, 入射光に対して円対称な溶液から の散乱, 粉末回折のような膜系からの散乱, そして配向 したゲルや笳肉ファイバからの回折の 3 種に大別され る. 理研の研究としては, 筆者の専門である蛋白質溶液 からの散乱と配向したゲルや筋肉ファイバが主なテーマ となる。

\section{$1.1 \mathrm{X}$ 線溶液散乱とは}

$X$ 線溶液散乱の分解能がどのようになるか示したのが 図1である. 乳酸脱水素酵素結晶構造解析の座標2) 図 1 （a）を用いて散乱曲線を計算すると, 図 1 (b) となり, 散 乱角の内側には回転半径や原点散乱強度, 外側にいくに したがって形状の寄与が散乱に大きく関与する．溶液散 乱は位相の情報が失われているので, 散乱曲線からモデ ル計算等を行い構造を評価する. 蛋白質溶液からモデル 計算するのに球面調和関数展開近似 ${ }^{3)}$ がよく使われる. フィットする散乱角領域で分解能が上がる様子を説明し たのが図 1 (c), (d) である. 散乱角の小さな領域では蛋 白質は球状であるが, フィットする散乱角を広げること により乳酸脱水素の 4 量体の特徴が現れてくる.さらに
散乱角の大きなところではリップルが見受けられるが, これはサブユニットの相関によるものである．これらの モデル計算は一般に不安定で, 建設する立場から言うと いかに誤差の小さいデー夕を得ることが出来るかがサイ エンスの結果として大きく反映されることになる．

\section{$1.2 \mathrm{X}$ 線溶液散乱の構造生物学研究での役割}

近年蛋白質結晶構造解析が急速に進展し, 高分解能の 構造が誰にでも迅速に得られる中で, 構造生物学の中で の小角散乱の役割としては大きく2つに分類できるであ ろう.4)一つは結晶化が難しいあるいは結晶構造解析で はできない研究. 第 2 は時分割測定である. 前者の代表例 としては蛋白質折れ畳み問題解明のためのランダムコイ ル状態やモルテングロブル状態での蛋白質での構造.5) あ るいは結晶化されにくい巨大蛋白質複合体6) や脂質やミ セル，糖鎖を伴う蛋白質の構造. 後者としては蛋白質の 折れ畳み反応7) や酵素の基質結合などに伴う大きな構造 変化. 溶液散乱ではないが筋肉の収縮反応 8), 9) や光反応 に伴う膜蛋白質の構造変化10) が挙げられる. 蛋白質の多 くは一つのポリペプチド鎖からではなく複数のポリペプ チド鎖からなり，多くの生体内反応が蛋白質あるいはサ ブユニット間相互間といった弱い結合によって制御され ている. 高分解能の原子座標に基づく残基レベルでの議 論はもちろん必要であるが, そのような弱い相互作用を 物理化学的に研究するには生体により近い状態で測定す ることが大事であると筆者は考える。 


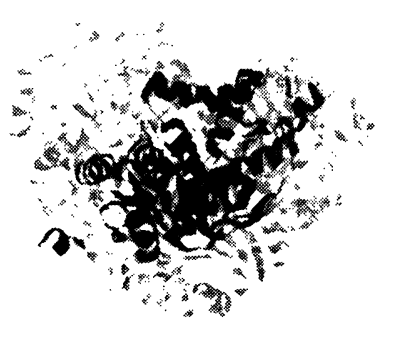

(a)

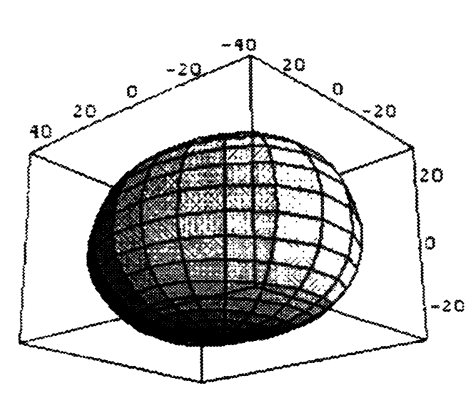

(c)

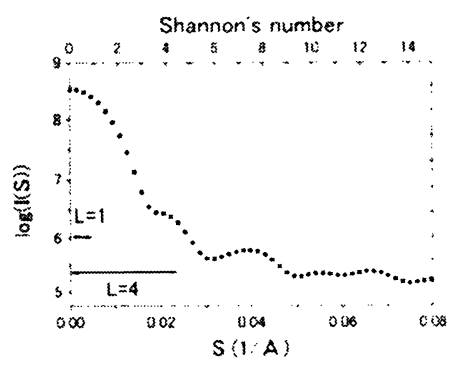

(b)

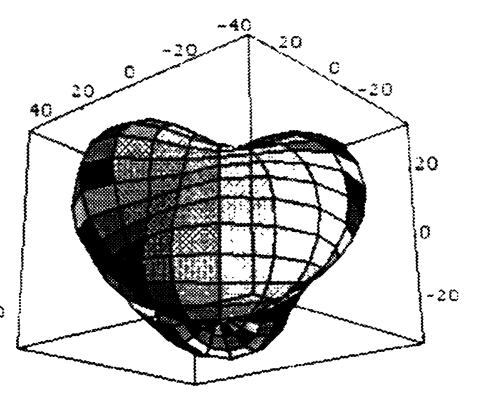

(d)

図 1 蛋白質 $\mathrm{X}$ 線溶液散乱の分解能. (a) 乳酸脱水素酵素の結晶構造 $\left(6 \mathrm{ldh}^{2}\right)$ ), (b) 結晶構造から計算された溶液散乱. $\mathrm{S}=$ $2 \sin \theta / \lambda$ : $2 \theta$, 乱角 $\lambda$ 波長. (c) $S<0.006 \AA^{-1}$ に相当する分解能で球面調和関数展開したもの. (c) $S<0.0243 \AA^{-1}$ に 相当する分解能で球面調和関数展開したもの. (Resolution of solution X-ray scattering of protein.)

\section{3 高圧下での X線溶液散乱}

筆者は特に高圧下での $\mathrm{X}$ 線溶液散乱に興味を持ってい る. 小さな蛋白質は生理条件下では 5000 ないし 6000 気 圧にならないと変性しないが, 複数のサブユニットから なる蛋白質では 2000 気圧前後で個々のサブユニットの 2 次構造が変わらずに乘離会合を行う. ${ }^{11)}$ 静水圧を用いる 最大の利点は, 熱や変性剤によるものと違い, 内部エネ ルギーを変えずに自由エネルギーを変化させることがで き, 微妙な実験条件の調整が簡便にできることである.正 しく折れ睤まらずに会合をおこした蛋白質が圧をかける ことにより正しく折れ畳まり, 圧を解除した後も分散し ている例が報告されており, 工業的にも静水圧の利用が 大きく着目されている.12) しかしながら, 円2色偏光も 測定できず, 結晶構造解析も困難で, NMR では高分子量 蛋白質が扱えない中, 構造生物学的な研究はなかなか進 展していない。ル・シャトリエの法則から明らかなよう に, 圧力が変化すると体積が変化する.X 線溶液散乱は 元々大きさ (体積) の変化の検出に適しており, 極めて 有効な測定手段となりうる. 筆者は立命館大学の加藤博 士との共同研究により, 世界で始めて蛋白質溶液の定量 的な X 線散乱測定に成功した. ${ }^{13)}$ その経験に基づきビー ムラインの最適化設計を行った。

\section{2. ビームライン}

結晶解析ビームラインを含めて BL45XU 全体の仕様に
ついてはビームライン担当者の山本氏らが,1) また小角 散乱実験ステーションについては筆者らがすでに報告を 出しており，14)，15）詳しくはそちらを参照されたい. 本稿 では書き落としている部分を中心に簡潔に述べたい。

\section{1 光学系}

高圧下での X 線溶液散乱を測定する上で重要な点は 3 つある.すなわち, 小さなビームサイズ, 短い波長そし て寄生散乱の低減である．BL45XUでは，小角散乱が使 用する波長は通常 $1.0 \AA$ 凡゙, 分岐を行うダイアモンドモ ノクロメーターは7 keV〜 $14 \mathrm{keV}$ まで連続的に波長を変 えることができるが，実質上変更することは希である．1 Åの波長を使用することにより高圧セルの空材として使 用するダイヤモンドの吸収を大幅に減らすことができ， 従来型高圧セルでは, 透過率が $1.5 \AA$ と比べ約 7 倍にな る. ${ }^{13)} \mathrm{BL} 45 X U$ の発光点でのビームサイズは $0.394 \times$ $0.0271 \mathrm{~mm}$ (水平 $\times$ 垂直), 発散は小さく $19.5 \mu \mathrm{rad} \times 8.83$ $\mu \mathrm{rad}$ (水平 $\times$ 垂直) である.この特徴を生かしてできる だけ寄生散乱を減らすような設計がなされている．集光 系はロヂウムコートされた 2 枚の円筒平面型ミラーを $40.5 \mathrm{~m}$ と $41.7 \mathrm{~m}$ の位置に K-B 型配置し, $58.2 \mathrm{~m}$ の位置に フォーカス点を置いている. ミラーの見込み角は $4 \mathrm{mrad}$

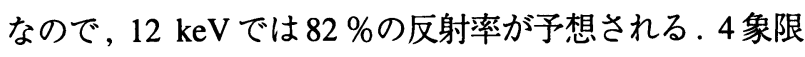
スリットは分光器の直後, ミラーの直後, サンプル前実 験ハッチに2 台設置されている．小角散乱実験では頻繁 にスリットを微調する．それぞれのスリットの下流には 
真空中に強度モニターが設置され簡便に設定することが できる。

\section{2 実験ハッチ}

試料位置は光源より $56.4 \mathrm{~m}$ ないしは $56.0 \mathrm{~m}$ で固定す る . ミラーの焦点はカメラ長を変更するときにはいじら ない. 試料位置を固定にすることによって非常に試料周 りの自由度が高くなっている. カメラ長の変更は検出器 架台を移動させ真空パスを付け替えることにより行われ る. カメラ長は, $0.6,1.0,1.8,2.2 \mathrm{~m}$ と 4 種類用意されて いる. 現在の焦点サイズはおよそ半值幅で $0.4 \mathrm{~mm}$ (水 平) $\times 0.2 \mathrm{~mm}$ (垂直) である.ガードスリットにおいて は開口部が $0.8 \mathrm{~mm}$ (水平) $\times 0.4 \mathrm{~mm}$ (垂直) である. サイ クルごとに若干変化するが, 試料位置では $1 \mathrm{~mm}$ 角以内 にはすべて収まっている，標準溶液散乱用セルは温度コ ントロール可能で, 開口部 $4 \mathrm{~mm} \phi$, 光路長 $3 \mathrm{~mm}$ (容量 約 $0.05 \mathrm{ml}$ ) を用いている.ビームストップが入っている 真空チェンバー内に可動式アームが設置されており, 吸 収を測定する場合にはビームストップ前にカプトン膜を 置きそのピーク積分值により測定される．図２に高圧ス トップドフロー装置を設置した時の実験ハッチ内の様子 を示す. 試料位置での光量は $100 \mathrm{~mA}$ 運転時で $10^{12}$ フォ トンである

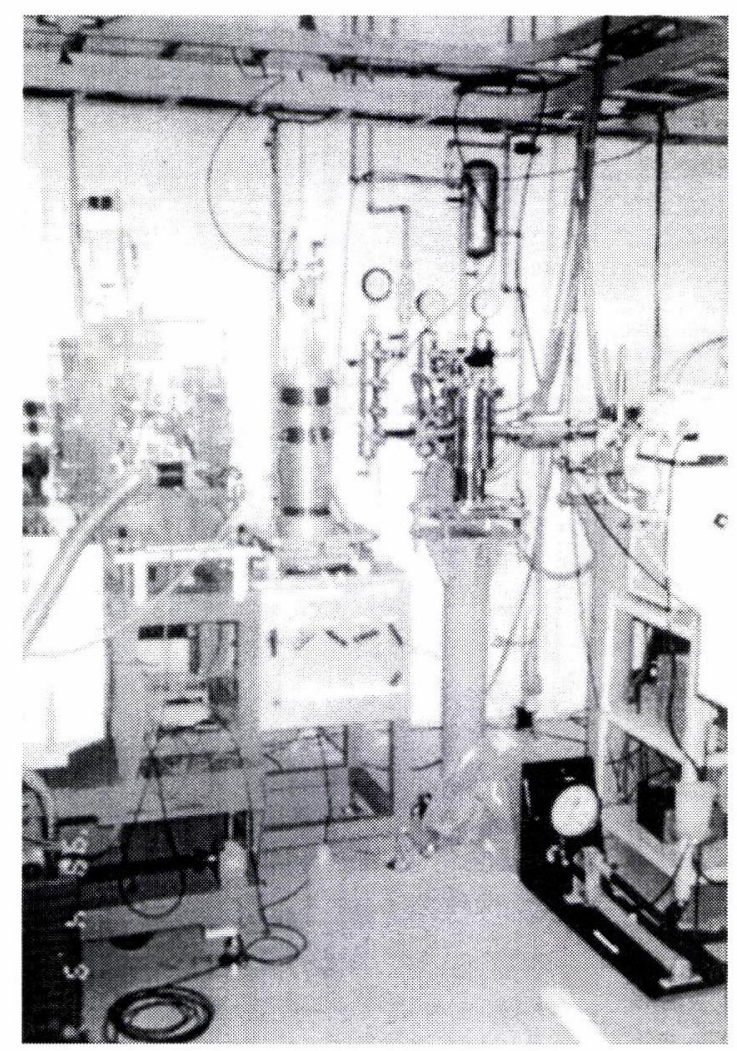

図2 BL45XU 小角散乱実験ステーション内部. 通常の試 料架台の代わりに高圧ストップドフローを設置してい る. (The inside of SAXS experimental station at BL45XU.)

\subsection{BL45XU 小角散乱の SPring-8 内および世界的な位 置付け}

BL45XU と他の ESRF, APS の挿入光源小角散乱のビ ームラインとを比較した時に一番大きな差は光量であろ う. ESRFのID2 などと比較しても 1 桁低い.16)これは BL45XU の挿入光源が垂直偏光で，しかもSPring-8標準 型と比べ $1 / 3$ の長さのみを小角が使用していることと, ミ ラーを1つではなく2つにしているからと考えられる.さ らに大きな違いはカメラ長である. ESRFが $10 \mathrm{~m}$ 程度の カメラ長を持つのに対して, BL45XUは $2 \mathrm{~m}$ 少ししかな く, 90 年代に建設された小角散乱のビームラインの中で はとりわけカメラ長が短い部類に入り, 今後の課題とな っている. 光量の点から考えると, およそ第 2 世代のウイ グラーを用いた小角散乱ビームライン I 17)，18）と同程度， ビームサイズでは第 3 世代のビームラインと言える。

SPring-8 内では, 本ビームラインを含めて BL40B2, ${ }^{19}$ BL40XU ${ }^{20)}$ と, 3 本のビームラインが共同利用の小角散乱 実験に供されている．他の 2 本とも小角散乱専用ではな く, 結晶構造解析やイメージングといった用途との相乗 りである。それぞれの特徴を一言で述べると，BL40B2 が波長可変なビームライン, BL40XUは高光量ビームラ インでBL45XUより 3 桁強いビームラインである。これ から共同利用申請される方はそれぞれの特徴にあったビ ームラインを選んでいただきたい。

\section{4 検出器 21)}

過去, 1 次元位置判別型比例計数管 (PSPC) に代表さ れるガス型検出器以外の検出器が溶液散乱において定量 的な仕事に使われることはほとんどなかった．しかし現 在の標準的なガス検出器では $10^{4} \mathrm{phtons} / \mathrm{s} / \mathrm{mm}^{2}$ 程度の散 乱光しか処理できず, 第 3 世代からの高光量をカバーす ることは難しい. 我々は, 東大雨宮氏らによって開発され たX線イメージインテンシファイアー+ CCD 検出器 ${ }^{22}$ $(\mathrm{XR}-\mathrm{II}+\mathrm{CCD})$ を採用し，ビームライン立ち上げ以来 その溶液散乱への応用に最も多くのビームタイムを割い てきた $\mathrm{XR}-\mathrm{II}+\mathrm{CCD}$ は, X線光子を光に変換し, さら に光電子の形で集光して冷却 CCD 上で計測するという原 理の検出器である.この検出器の特徵は, $5 \times 10^{7} \mathrm{ph}$ tons $/ \mathrm{s} / \mathrm{mm}^{2}$ という高散乱強度においても検出可能で，し かも CCD を使用しているのでビデオレートではあるが時 分割測定も可能である. しかし当初から, 検出面の中心 部から周辺部にかけて系統的に画像がひずみ, 検出感度 が変わることが報告されており，さまざまな補正ソフト も開発されてきた.23), 24) 図3は等間隔格子状に穴を開け たマスクを XR - II + CCDの前に置き, イメージングプ レートとの比較でずれを測定し, それを検出器の動径方 向にプロットしたものである.21) 像の歪み（図3(a)) お よび感度の不均一性（図3(b)）は検出面の角度方向にあ まりよらず，しかも中心部では両者とも非常に小さい事 


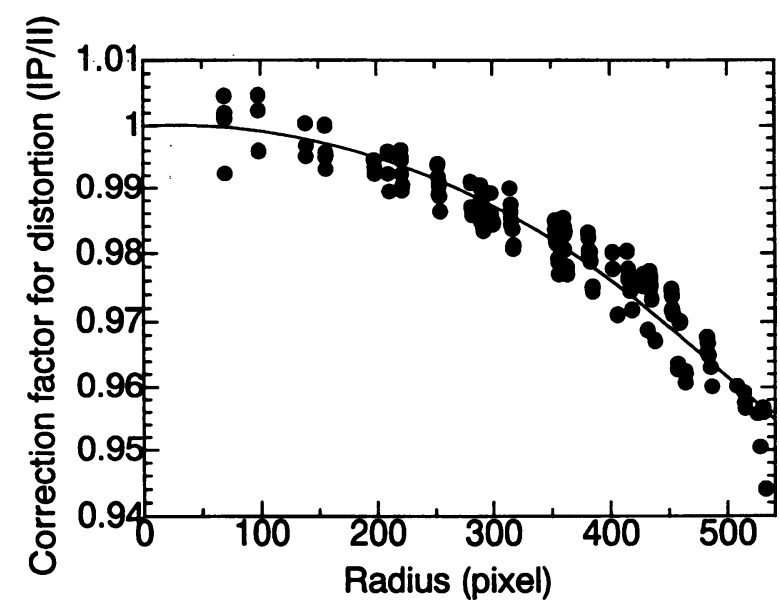

(a)

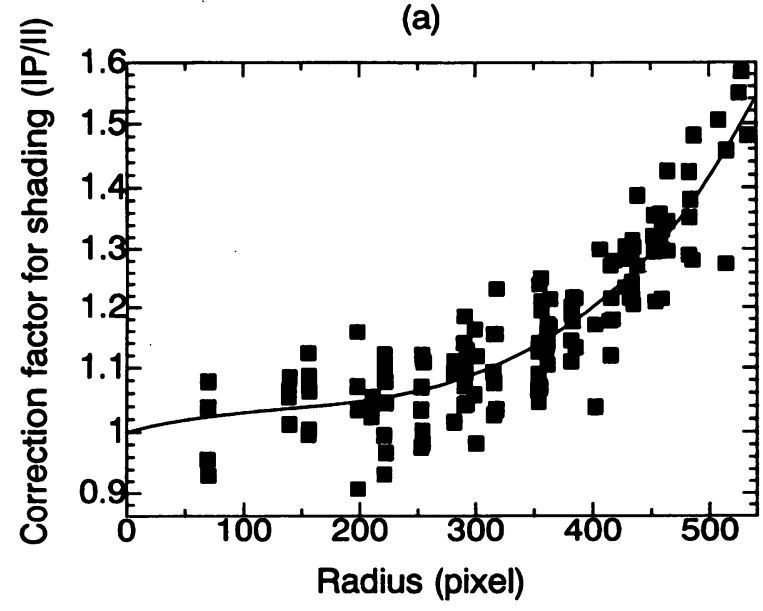

(b)

図3 XR - II + CCD 検出器の歪みおよび感度不均一性. 検 出器の前面にグリッドマスクをおき，イメージングプ レートとの比較から XR - II + CCD 検出器の歪み （a）と感度不均一性（b）に対する補正係数を検出器 中心から動径方向にプロットしたもの.21) (Deviation and shading of XR $-\mathrm{II}+\mathrm{CCD}$ detector.)

がわかる.我々はこれらの事実と補正用デー夕取得の実 際上の問題点を考慮し, 検出器の中心部だけを補正無し で取得し, それらの像が実際の解析結果にどのくらい影 響し, 従来のPSPCの結果と違うかを評価した。サンプ ルとしてポリスチレンラテックスに着目した．これは大 きさ分布も狭く，その高周波構造をもつ散乱曲線が単純 球でよく近似されることがわかっている．図4は，溶媒 の散乱をひいたポリスチレンラテックスの XR - II + CCD と PSPCで測定された散乱曲線である.21) 一見して わかることであるが, XR - II + CCD 検出器は実質上ダ イナミックレンジが 2 桁程度しかないことがわかる.中 心部にX 線がはいらないようにマスクをかけると, XR一 II + CCD のデータはPSPCのデータと一致した。つまり ダイナミックレンジを満たすような測定をしてやると正 しい解析結果をだすことは可能である. 図3から評価す

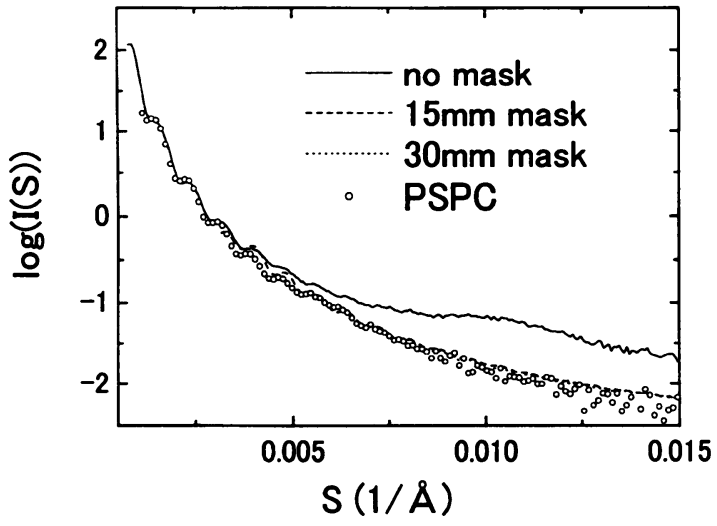

図 $4 \mathrm{XR}$ - II + CCD と PSPC の比較. ラテックス溶液散乱 をPSPC，XR - II + CCDで計測したもの.21（The comparison between XR - II + CCD and PSPC.)

ると，回転半径などは 55 ピクセル以内の中心領域を使用 すれば $1 \%$ 以下の誤差となり補正の必要はない。また動 径分布関数 $\mathrm{P}(\mathrm{r})$ などもダイナミックレンジに気をつけ ていれば差異は観測されなかった。

\section{3. ビームラインの評価}

BL45XUではすべてが溶液散乱の実験ではない.10), 25)-27) 実際に蛋白質溶液散乱の実験を行っているのは, 60 \%程 度かとは思われるが，筆者の関与している溶液散乱にお けるビームラインの特徴について述べたい。

\section{1 蛋白質の放射線損傷}

挿入光源光を用いた X 線溶液散乱測定で最初に懸念さ れたのは，X線を照射されることによる蛋白質溶液の放 射線損傷である．これは，すでに筑波のフォトンファク トリーの偏光電磁石ビームラインでも報告されていた し,28) 近年建設された第 2 世代のウイグラービームライ ン，第 3 世代の挿入光源のいずれでも放射線損傷が報告 されている.16)－18) 具体的には，長時間 X線を照射してい ると会合がおこったり，色のついている蛋白質では色素 が落ちたりする現象である．一般に, 放射線損傷は X線 が照射されたことによる溶液中でのラジカル生成による ものとされるが，X線小角散乱で問題とされる放射線損 傷の詳細はわかっていない. 第2世代では, ラジカルを吸 収するような吸収剤として，DTT（ジチオスレイトール） のような還元剤を低濃度入れることがよくなされていた。 第2 世代のウイグラービームラインでは，フローセルを 作成し，常に蛋白質を流してX線が照射される位置に新 鮮な蛋白質を送りつづけることがなされた.18) しかし，現 実的にはそれだけ蛋白質の量を増やさなくてはならず， 対象となる試料の蛋白質が限定されることになる．ESRF

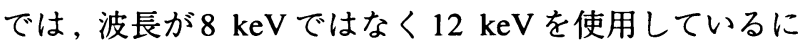
もかかわらず $X$ 線照射 1 秒以内に照射されたところに泡 
が生成され，損傷を受けることが報告されている.16) BL45XUでは,リゾチウム溶液にX 線照射を行い, 1 秒ご とに散乱曲線を記録し, 回転半径の変化を調べたところ, 15 秒たつと回転半径が明らかに増加し, 泡の生成も確認 された. 通常の静的な測定では, 露光時間 1 秒を目安にし ている.しかしフェリチンなどのように放射線損傷に対 して弱いものもあり，新規蛋白質を測定する場合は照射 時間と回転半径の関係をなるべく調べるようにしている．

\section{2 希薄溶液からの散乱測定}

$\mathrm{XR}-\mathrm{II}+\mathrm{CCD}$ はガス検出器に比べ検出効率が高く, しかも強力な挿入光源とあいまって非常に高い $\mathrm{S} / \mathrm{N}$ 比の データが得られる. 分子量 18000 ダルトン程度の蛋白質 でも, $0.3 \mathrm{mg} / \mathrm{ml}$ 程度の濃度で回転半径を約 1 秒で正確に 決定できる。これは筑波のフォトンファクトリーBL10C などでの濃度と比べ約 $1 / 5$ である. 光散乱や平衡沈降法と いった大きさを決める他の測定方法に比べて, 低濃度で 測定できるようになり，X線溶液散乱の用途が大きく広 がった.その 1 例として, 磯貝氏らの人工蛋白質の設計評 価がある.29) 設計評価を行う上で, 人工蛋白質がどのよう なサイズになっているのかを知るのは非常に大切である. この人工蛋白質は, ターゲットの立体構造（ミオグロビ ン）をとるように, 全アミノ酸配列（153残基）を理論的 に設計したものである。一般に, 人工蛋白質は天然の蛋 白質に比べ, 3 次構造がうまく折れ睤まれていないことが 多く，しかも高濃度にすると沈殿したり会合したりする。 我々は希薄溶液の散乱測定によってこの人工蛋白質の回 転半径を精密に測定し,へムの結合に伴ってこのサイズ が減少することを証明した。

別の例としては, 理研· Bolze 氏, 姫工大 ·内藤氏ら のバイセルの仕事がある.30) バイセルとは，2 種類の脂質 DMPC と DHPC の水溶液中での混合物で, ディスク状の 形状を形成するものと考えられている．バイセルは膜蛋 白質, ペプチドを研究する際, 高分解能 NMRでは非常 によく使用されるモデル膜系である．しかしながらバイ セル自身の構造・物性についてはよく解明されていない． 特に溶液 NMR で使用される低濃度バイセルに関しては， $\mathrm{X}$ 線溶液散乱測定を行うことが不可能で, 形状に関する 情報がなかった．X線溶液散乱と ${ }^{31} \mathrm{PNMR}$ を用いて，3\% から $16 \%$ の濃度範囲では分散しているにもかかわらず， $1 \%$ \%゙はバイセルが積層していることが初めてわかった。

近年, 生化学精製あるいは解析評価が飛躍的に向上し ており，蛋白質精製量は大幅に減少している。にもかか わらず, 従来 X 線蛋白質溶液散乱は最もサンプル量の必 要な方法論であった. サンプルの量的な改善は今後さら なる他の測定方法との交流・相関研究を促進していくと 思われる．

\section{3 小角散乱測定}

BL45XUは，非常に寄生散乱を減らす設計になってお
り，小さな散乱角を測定するのに適している，ウイルス や巨大な蛋白質複合体はサイズが大きいので, 構造情報 が非常に散乱角の小さな部分に含まれることになる．既 に第 2 世代の放射光施設の小角分解能は約 $100 \mathrm{~nm}$ であ る. BL45XUは, カメラ長が $2.2 \mathrm{~m}$ しかないが, それで も最小小角分解能は $150 \mathrm{~nm}$ 程度あり，現在日本で唯一 1 ̊̊の波長で $100 \mathrm{~nm}$ 以上を計測できるビームラインであ る. 九州大学麻生氏らとの共同研究では, ピルビン酸デ ヒドロゲナーゼ多酵素複合体という, 分子量 $1.5 \mathrm{MDa}$ の 超分子複合体の溶液散乱を行っている.6)この蛋白質は, ジヒドロリポアミドS-アセチルトランスフェラーゼ (E2), ピルビン酸デヒドロゲナーゼ（E1）+ジヒドロリポ アミドデヒドロゲナーゼ（E3）の3 種類の蛋白質からな り，3 種類の反応を多酵素複合体で行う. 特に, E2 2 巨 大構造体のコアとなっているが, 結晶構造解析により正 12 面体の形状をしていることが知られている.31) E1，E3 は非常に弱い力で結合しており, その構造安定のメカニ ズムの研究に小角散乱を用いている.32)このように小角 分解能の向上は, 今まで得られなかったディメンジョン の情報をもたらすが, 一方, 今までビームストップの内 側に散乱され見えなかった大きな会合体なども問題とな り，より均一な試料を準備することが大きな複合体を扱 う場合重要となる。

\section{4 時分割測定}

蛋白質がランダムコイル状態から折れ畳む反応や，基 質結合に伴う大きな蛋白質構造変化などは, 結晶下では 行うことは難しく，X線溶液散乱が直接的に“姿の変化” をみる唯一の手段となる．時分割測定で最もよく使用さ

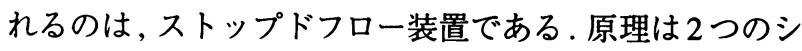
リンジに, 混合したい溶夜を引き込み，そのシリンジの シャフトを動かすことにより2液を混合する．混合され た溶液は観測部へと導かれ，X線が照射される. SPring-8 で使用しているストップドフロー装置は, 観測部に直径 $2 \mathrm{~mm}$ のキャピラリーを使用している. 従来の $X$ 線スト ップドフロー装置の場合, ビームサイズが大きいため観 測部が大きく, 一度混合された液体が広がるために泡が 発生しやすい等の問題があった．またキャピラリーを採 用しているため, $X$ 線と直角方向に分光や光刺激などが できるようにもなっている.デットタイムはおおおよそ数 $\mathrm{msec}$ 程度である . 検出器はXR - II + CCD を使用してい る. この検出器の特性から, 検出器の中心部を使用する ことが望ましく, その点, 波長が短く光量もありカメラ 長を短くしてもビームサイズが絞れているため, 小角部 が計測できる本ビームラインは時分割測定に適している といえよう．XR－II + CCDは, $36.36 \mathrm{msec} /$ frameのビ デオレートで像を連続的に取得できるが，取得する像の サイズを小さくし, 分解能をおとせばさらに早いレート で像を取得できる，筆者は，磯貝氏らと共同でアポミオ 
グロビンを使用して折れ畳み反応を計測した.33) Wright らが 1200 回積算して計測した散乱よりはるかに良い $\mathrm{S} / \mathrm{N}$ で, 最高 $7.84 \mathrm{msec} / \mathrm{frame}, 50$ 回積算で散乱曲線を得るこ とができた.7)また,アルドラーゼを用いた変性実験では， 散乱角が実空間で $150 \AA ̊$ から $8 \AA$ の範囲を同時にビデオ レートで測定することができることを示した、特に，実 空間で $30 \AA ̊ 丿$ む高分解能の領域, すなわち中広角領 域は, 従来長時間露光でも測定が難しかった. 回転半径 や分子量に比例する原点散乱強度といった情報だけでな く, サブユニットの相関関数や $\alpha$-ヘリックス由来の $10 \AA$ 近傍ピーク変化の様子が, 時間とともに違った位相で変 化していく事がわかった.34)

\section{5 時分割測定の解析}

現在の世界トップレベルでは, 単に回転半径や積分強 度の変化だけでなく, 反応途中の中間体の散乱曲線を平 均值である観測デー夕から分離することが行われている． これらは, 反応の途中で系に存在する各状態数の濃度を 溶液散乱以外の方法, 蛍光や円 2 色偏光法で測定し, それ に基づいて各散乱曲線を計算している.35) BL45XUで得 られるデー夕は非常に $\mathrm{S} / \mathrm{N}$ が良く, 単に回転半径を計算 できるだけでなく散乱曲線を解析できるレベルにある。 そこで, 散乱曲線から得られたデータのみで, 系に存在 する状態数や各散乱曲線を特異值分解法に基づき分離す ることに成功した.33), 34) これは単に手間が減るというだ けではない. 例えば 2 次構造と 3 次構造の構造変化の反 応定数が違う時には, 途中で反応を止め, 円 2 色偏光性 から各状態の濃度を決めても, その濃度を散乱曲線の解 析には使えない. なぜなら，与えられた時間での 2 次構 造から見た濃度と 3 次構造から見た濃度が違うからであ る.したがって, 従来の方法では各散乱曲線を求めるこ とはできないが, 筆者の方法ではそれが可能となる．今 後は構造変化がより小さな系でどれだけできるかが課題 である.

\subsection{Ab initio shape determination への応用}

\subsection{1 ab initio shape determination とは}

ab initio shape determination とは, 小角散乱曲線に基 づいて蛋白質の形状を決めることである．蛋白質は，低 分解能 ( $30 \AA)$ で見たときに電子密度は一定で散乱曲 線は形状のみの関数となる. 昔から蛋白質を球充填モデ ルで表し散乱曲線に対して最適化することは行われてき たが, 容易に局所最小値に捕らわれ，なかなか期待通りの 結果は得られなかった. 近年, 非線形最小二乗法の劇的な 進歩により，今新たに注目をあびている。遺伝アルゴリズ ム37)，あるいは焼きなまし法 (simulated annealing) 37) と いったアルゴリズムを用いている．図5は，Svergun博士 の作成した焼きなまし法によるプログラムで, リゾチウ 厶の 1 次元散乱曲線からの 3 次元形状を計算した例であ る. 蛋白質結晶構造の座標をリボンモデルで表し, 計算
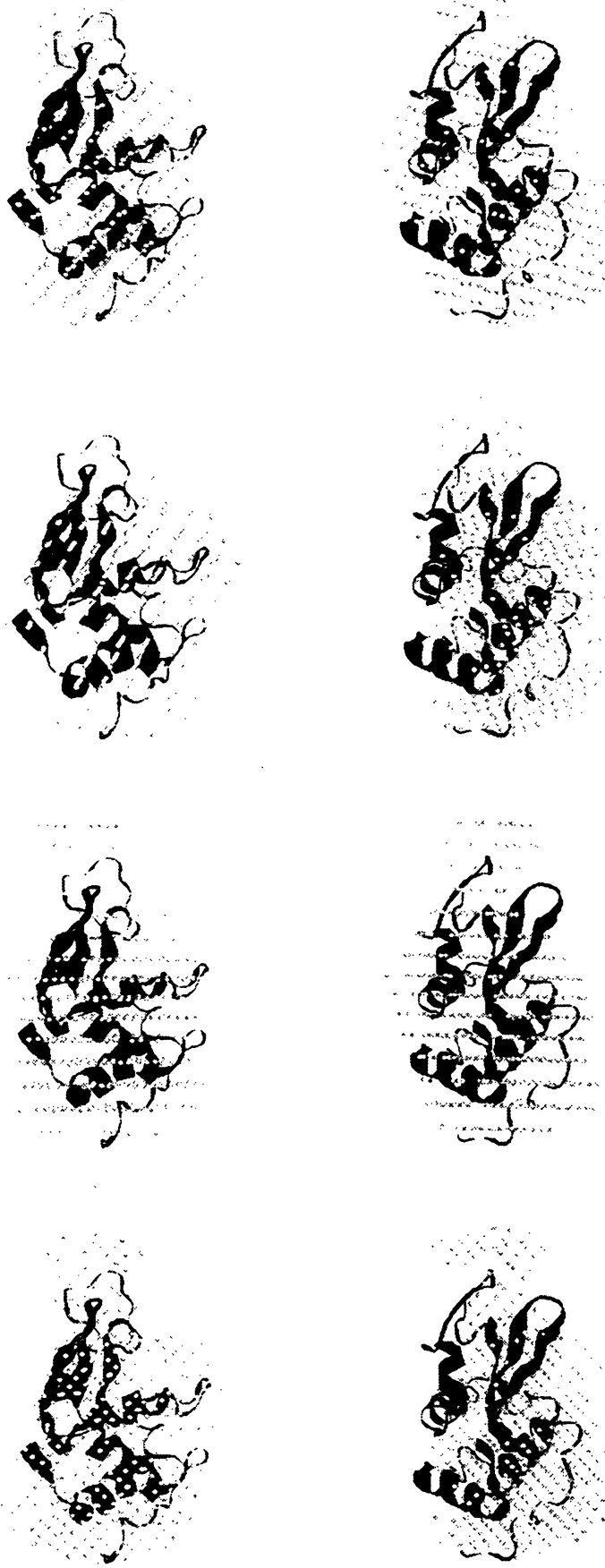

図 5 焼きなまし法DAMMINによる球充填モデルの安定 性、リゾチウムのPSPCによる同一実験データから

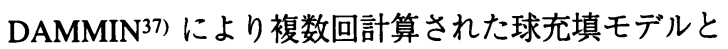
結晶座標をリボンモデルで重ね書きしたもの. 右側は 90 度ずらした図. 計算結果は安定していることがわ かる. (The stability of simulated annealing method, DAMMIN.)

された球充填モデルと重ね書きしたものである．非常に リゾチウムの特徴を捉えていることが良くわかる．プロ グラムを何回実行しても解は安定しているように見える. 同様の事が遺伝アルゴリズムを用いた計算でも確認され 


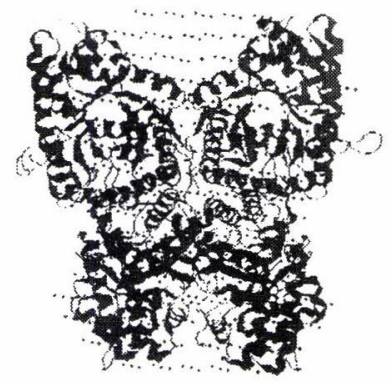

(a)

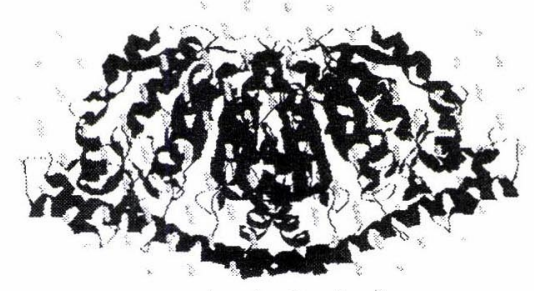

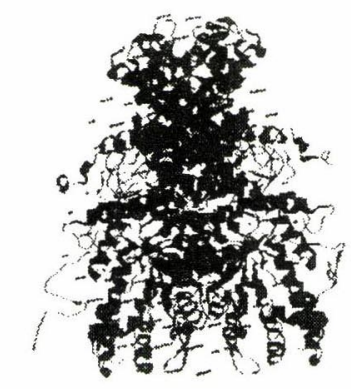

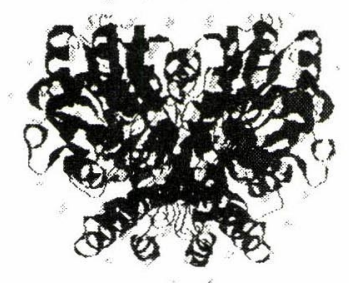

(b)

図6 BL45XUのデー夕の焼きなまし法DAMMINへの応用（a)アルドラーゼ時分割データから分離された native 状態アル ドラーゼ散乱曲線 35) に対するDAMMIN の出力（点）と結晶座標（リボン）。(b)アミノ基転移醳素散乱曲線 42)に対 するDAMMINの出力 (点) と結晶座標（リボン). (The application of XR - II + CCD data of BL45XU on simulated annealing method, DAMMIN.)

ている．何故そのような事が可能なのであろうか？ シ ヤノンのサンプリング定理に基づき散乱曲線の持つ情報 量を考えてみよう.38) シャノンのサンプリング定理によ り定義される情報量, シャノン数は, 最大観測角 $\mathrm{S}$ を最 大長の 2 倍で割ったものである. 例えば最大長 $80 \AA$ の蛋 白質を $30 \AA$ 分解能すなわち $\mathrm{S}<0.03$ まで測定すれば, シャノン数で 5 程度となる. 与えられた分解能に対し, 球 面調和関数展開近似より安定かつユニークに決定できる パラメーター数は, シャノン数の 1.5 倍程度であり, 経験 的には 15 から 20 の独立パラメーターは散乱曲線から決 定できる。したがって与えられた分解能に対する形状の 持つ情報量はそれに相当すると考えられる. しかし ab initio shape determinationのパラメーター数は多く, 不安定 な解になるはずである，それでもなおかつユニークでは ないにせよ安定な解になるのは, 2つの要因があるのでは ないかと筆者は考える.一つは超解像である. Harrison らは, 物体の広がりがあらかじめわかっている時に, そ のフーリエ変換である観測信号を計測系の遮断周波数よ り細かくサンプリングして, 行列の逆変換を行うことに より, 遮断周波数より带域を広げて信号を回復すること を示した.39) 実際, 我々が実験データを取るときのサンプ リングは, 明らかにシャノン数よりも大きい。二つ目は 決めようとする対象が蛋白質であるからである。蛋白質 の形状は連続的でしかも表面積を最小にするように表面 が非常にスムーズである。焼きなまし法においても, 単 日本結晶学会誌 第 42 巻 第 1 号 (2000)
に散乱曲線との二乗差の項だけでなく, 連続性とスムー ズになるようにペナルティ項を入れている. 現在モデル 計算でわかっている不安定な解になる形状は, 非常に平 ベったい円盤である。

3.6.2 BL45XUにおける ab initio shape determination のチェック

前項で述べた方法論が, BL45XUから得られたデータ に対してどれぐらい有効か, 焼きなまし法を使用して計 算された球充填モデルを 2 例について図 6 に示す.サン プルとしては, 低分解能でも形状がわかりやすいオリゴ マー蛋白質, アルドラーゼ (4 量体) 40) とアミノ基転移 酵素 (2 量体) 41$)$ について行った. 実験データ以外に, 分 子の対称性を拘束条件として計算した. 図6 (a) では, 時 分割実験デー夕から分離された散乱曲線にもかかわらず， アルドラーゼのねじれたような形状が計算された. 図 6 (b) では, 外形はほぼ一致するものの細部では結晶構造 と違っている。いずれの場合も, 計算された形状が蛋白 質結晶座標の特徴とよく一致する事がわかる. 現在 BL45XUで扱っている蛋白質は限られているので，す心゙ ての場合に有効か判断はできないが, 今後データを蓄積 しどのような場合に有効か評価する予定である．

\section{4. 今後の展開}

最初に書いたように，このビームラインの建設目標は 静水圧下におけるX 線溶液散乱測定を最適化することで 
ある. 残念ながら高圧測定はいまだBL45XU では定常化

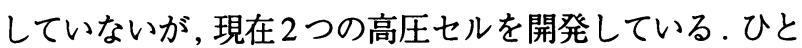
つは耐圧 5000 気圧の高圧ジャンプ装置である．従来の加 藤・藤澤型高圧セルは，測定に必要とされるサンプル量 が多く $(1.5 \mathrm{mg} / \mathrm{ml} \sim 2 \mathrm{mg} / \mathrm{ml})$ ，しかもサンプルの交換 が大変であった.13) 従来とはまったく違う高圧シールを 導入することにより，空材ダイヤモンドとほほ同じ径の 空プラグが可能となり，必要な体積も $0.1 \mathrm{ml}$ となった。 現在，最終的な試験を繰り返し，定量性を確かめてい る.42)さらに我々は, 高圧下（<2000気圧）にて 2 液を 混合し，その反応過程をX 線溶液散乱で測定する高圧ス トップドフロー装置を開発中である（図2）。これらの装 置は，開発するのに多大なビーム夕イムを必要とするの で，専用ビームラインとしてはふさわしいテーマである といえる。この数年我々が培ったビームラインでの散乱 測定技術，時分割測定解析技術，散乱曲線解析技術とあ いまって，BL45XUでしかできないサイエンスができる 日が近づいていると言えよう。

\section{謝 辞}

BL45XU 小角散乱ブランチに建設協力いただいた方々， JASRI の井上勝晶博士, 岩本裕之博士, 八木直人博士, 植木龍夫博士, 大阪大学の猪子洋二博士，岡俊彦氏およ び結晶ブランチを建設された理研の山本雅貴博士, 熊坂 崇博士らに深く感謝いたします.アミノ基転移酵素は大 阪大学の石嶋潤氏の好意により使わせていただきました。 焼きなまし法によるプログラム DAMMIN はEMBL 。 HASY-Labの Dmitri Svergun 博士の好意により使用させ ていただきました．最後にBL45XU 小角散乱ブランチの 高度化は, 理研の石川哲也博士, 前田雄一郎博士のご尽 力をいただいております。

\section{文 献}

1) M. Yamamoto, T. Fujisawa, M. Nakasako, T. Tanaka, T. Uruga, H. Kimura, H. Yamaoka, Y. Inoue, H. Iwasaki, T. Ishikawa, H. Kitamura and T. Ueki: Rev. Sci. Instrum. 66, 1833 (1995).

2) C. Abad-Zapatero, J. P. Griffith, J. L. Sussman and M. G. Rossmann: J. Mol. Biol. 198, 445 (1987).

3) D. I. Svergun, V. V. Volkov, M. B. Kozin and H. B. Stuhrmann: Acta. Cryst. A52, 419 (1996).

4）猪子洋二：次世代大型 $X$ 線光源研究会生体高分子II（非結晶） サブグループ計画趣意書「SPring-8によるX 線小角散乱」。

5) M. Kataoka, J. Flanagan, F. Tokunaga and D. M. Engelman: Synchrotron Radiation in Biosciences 187 (1994).

6) Y. Aso, T. Fujisawa, Y. Hiromasa, K. Meno and K. Kobayashi: PFOTON FACTORY ACTIVITY REPORT, 255 (1996).

7) D. Elizer, P. A. Jennings, P. E. Wright, S. Doniach, K. O. Hodgson and H. Tsuruta: Science 270, 487 (1995).

8) N. Yagi, K. Wakabayashi, H. Iwamoto, K. Horiuti, I. Kojima, T. C. Irving, Y. Takezawa, Y. Sugimoto, S. Iwamoto, T. Majima, Y. Amemiya and M. Ando: J Synchrotron Rad. 3, 305 (1996).
9) K. Wakabayashi, H. Tanaka, T. Kobayashi, Y. Amemiya, T. Hamanaka, S. Nishizawa, H. Sugi, T. Mitsui: Biophys J 49, 581 (1986).

10）岡 俊彦, 上久保裕生, 片岡幹雄: 放射光 12, 184 (1999).

11) T. Fujisawa, M. Kato and Y.Inoko: Biochemistry 38, 6411 (1999).

12) R. J. St. John, J. F. Carpenter and T. W. Randolph: Proc. Natl. Acad. Sci. USA 96, 13029 (1999).

13) M. Kato and T. Fujisawa: J. Synchrotron Rad. 5, 1282 (1998).

14）藤澤哲郎：放射光 12, 194 (1999).

15) T. Fujisawa, K. Inoue, T. Oka, H. Iwamoto, T. Uruga, T. Kumasaka, Y. Inoko, N. Yagi, M. Yamamoto and T. Ueki: submitted to $J$. Appl. Cryst (2000).

16) T. Narayan, P. Boesecke and O. Diat: Xith International conference on small-angle scattering, Brookhaven (1999).

17) H. Amentisch, M. Rappolt, M. Kriechbaum, H. Milo, P. Laggner, S. Bernstorff: J. Synchrotron Rad. 5506 (1998).

18) H. Tsuruta, S. Brennan, Z. U. Rek, T. C. Irving, W. H. Tompkins and K. O. Hodgson: J. Appl. Cryst. 31, 672 (1998).

19）三浦圭子, 井上勝晶, 河本正秀, 森山英明：理研シンポジウム (V), SPring-8 (2000)

20）八木直人, 井上勝晶, 鈴木 拓：第 13 回日本放射光学会年会· 放射光科学合同シンポジウム, 岡崎 (2000).

21) T. Fujisawa, Y. Inoko and N. Yagi: J. synchrotron rad. 6, 1106 (1999).

22) Y. Amemiya, K. Ito, N. Yagi, Y. Asano, K. Wakabayashi, T. Ueki and T. Endo: Rev. Sci. Instrum. 66, 2290 (1995).

23) A. P. Hammersley, S. O. Svensson and A. Thompson: Nucl. Instr. Meth. A 346, 312 (1994).

24) 伊藤 隆：博士号学位論文, 総合科学技術大学院 (1998).

25) T. Iwamoto, T. Suzuki and T.Fujisawa: Eur. J. of physiology 439, (2000).

26）鈴木 拓, 八木直人, 井上勝晶, 藤澤哲郎：第 13 回日本放射光学 会年会・放射光科学合同シンポジウム，岡崎 (2000).

27）竹森 重, 山口真紀, 八木直人, 森本幸生：第37 回日本生物物理 学会年会, 和光 (1999).

28）小島正樹，高橋健治，田之倉優，雨宮慶幸，伊藤和輝，木原 裕：第 13 回日本放射光学会年会・放射光科学合同シンポジウ 么, 岡崎 (2000)

29) Y. Isogai, M. Ota, T. Fujisawa, H. Izuno, M. Mukai, H. Nakamura, T. Iizuka, K. Nishikawa: Biochemistry 38, 7431 (1999).

30) J. Bolze, T. Fujisawa, A. Naito, T. Nagao, K. Norisada and H. Saito：第37 回日本生物物理学会年会, 和光 (2000).

31) T. Izard, A. Evarsson, M. D. Allen, A. H. Westphal, R. N. Perham A. de Kok and W. G. J. Hol: Proc. Natl. Acad. Sci. USA 96, 1240 (1999).

32）目野浩二, 麻生陽一, 藤澤哲郎, 石黒正恒：第43 回日本農芸化 学会年会, 福岡 (1999).

33）藤澤哲郎, 磯貝泰弘：第 37 回生物物理学会年会, 和光 (1999).

34）藤澤哲郎, 八木直人：同上

35) D. J. Segel, A. Bachmann, J. Hofrichter, K. O. Hodgson, S. Doniach and T. Kiefhaber: J. Mol. Biol 288, 489 (1999).

36) P. Chacon, F. Moran, J. F. Diaz, E. Pantos and J. M. Andreu: Biophys. J. 74, 2760 (1998).

37) D. I. Svergun: Biophys. J. 76, 2879 (1999).

38) P. B. Moore: J. Appl. Cryst. 13, 168 (1980).

39) J. H. Harris: J. Opt. Soc. Am. 54, 931 (1964).

40) N. Blom and J. Sygusch: Nat. Struct. Biol. 4, 36 (1997). 
41) J. Ishijima, T. Nakai, S. Kawaguchi, K. Hirotsu and S. Kuramitsu: J.B.C., in press (2000).

42）西川幸宏, 藤澤哲郎, 守時正人：第 13 回日本放射光学会年会. 放射光科学合同シンポジウム, 岡崎 (2000).

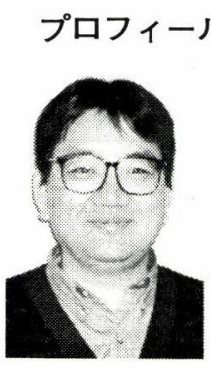

藤澤哲郎 Tetsuro FUJISAWA

理化学研究所 播磨研究所

Structural Biophysics Laboratory, RIKEN Harima Insitute/Spring-8

干 679-5148 兵庫県佐用郡三日月町光都 1-1-1

1-1-1 Kouto, Mikazuki, Sayo, Hyogo 679-5148, Japan

Tel. 0791-58-2815, Fax. 0791-58-2816

e-mail: fujisawa@sp8sun.spring8.or.jp 最終学歴: 大阪大学大学院基礎工学研究科博士課 程

専門分野：X線小角散乱, 生物物理学

現在のテーマ：筋蛋白質を中心とする蛋白質構造 物性

趣味：ビームタイム休止期間中のサイエンスがで きる時が最高の楽しみです。 